\title{
Ammonium removal from aqueous solution by ion-exchange using packed bed natural zeolite
}

\author{
Ahmet Demir*, Ahmet Günay and Eyyüp Debik \\ Yildiz Technical University, Department of Environmental Engineering, 80750, Istanbul, Turkey
}

\begin{abstract}
Ammonium removal from aqueous solution by a natural ion-exchange resin was investigated by considering the factors affecting the ammonium-exchange capacity including the zeolites' particle size, the loading flow rates and the impact of a number of regenerations upon the ion-exchange capacity. The resin column was exhausted by downflow at 10, 25, 50 and 75 bed volume $(\mathrm{BV}) / \mathrm{h}$, until effluent ammonium concentration of more than $10 \mathrm{mg} / \mathrm{N} \mathrm{NH}_{4}{ }^{+}$was achieved. The results indicate that conditioning of the zeolite improves the ion-exchange capacity and that the smaller particle size also causes a higher ion-exchange capacity due to greater available surface area. The actual ion-exchange capacity of the conditioned fine $(-1.00+0.125)$ and coarse $(-2.00+1.00) \mathrm{mm}$ clinoptilolite was found to be 0.57 and $0.38 \mathrm{meq} / \mathrm{g}$ zeolite, respectively.
\end{abstract}

\section{Introduction}

Zeolites are aluminosilicate minerals containing exchangeable alkaline and alkaline earth metal cations (normally $\mathrm{Na}^{+}, \mathrm{K}^{+}, \mathrm{Ca}^{++}$, and $\mathrm{Mg}^{++}$) in addition to water in their structural framework. The physical structure is porous, containing interconnected cavities in which the metal ions and water molecules are contained. Clinoptilolite is one of the natural zeolites used to remove cations such as heavy metals (Ahmed et al., 1998; Ouki and Kavannagh, 1999; Callejas et al., 2001) and ammonium ions from aqueous solutions (Mercer et al., 1970; Koon and Kaufman, 1975; Jorgensen and Barkacs, 1976; Klieve and Semmens, 1980; Schoeman, 1986).

The zeolite-rich tuffs of Bigadiç, in the nortwestern part of Turkey, are mainly coarse-grained, glassy, with ash tuffs on top (Sirkeciolu and Senatlar, 1995). The availability of natural zeolites in many countries facilitates low-cost treatment by ion-exchange systems (Mercer et al., 1970). The use of clinoptilolite as a resin has the following advantages:

- good performance of ammonium removal under low temperature;

- compact size and easy maintenance of the full-scale plants; and

- ammonium-ion selectivity (Singh and Prasad, 1997).

The widespread application of ion-exchange processes has led to the development of equipment that functions almost automatically and requires relatively little maintenance. While the total exchange capacity of clinoptilolite is somewhat less than that of synthetic organic resins, its selectivity for the ammonium ion gives it a distinct advantage over conventional exchange resins.

Among the technologies for ammonium control are such processes as air stripping, breakpoint chlorination, nitrificationdenitrification and ion-exchange (Metcalf and Eddy, 1991). Ionexchange seems to be an attractive method especially when lowcost minerals can be used as an exchanger.

\footnotetext{
* To whom all correspondence should be addressed.

용 +90212 2597070 (2865); fax: +90 212261 9041;

e-mail: ahmetd@yildiz.edu.tr

Received 9 October 2000; accepted in revised form 19 April 2002.
}

Ammonium removal form aqueous solution by ion-exchange has been investigated by many researchers (Koon and Kaufman, 1975; Gaspard et al., 1983; Schoeman, 1986; Haralambous at al., 1992). Koon and Kaufman (1975) were concerned with ammonium removal from municipal wastewater by clinoptilolite. Gaspard et al. (1983) examined the ammonium removal characteristics from drinking water by clinoptilolite. Schoeman (1986) evaluated $\mathrm{NH}_{3}-\mathrm{N}$ removal from an underground mine-water by South African clinoptilolite (Pratley) and compared it with Hector clinoptilolite from the USA. Haralambous at al. (1992) compared natural and synthetic zeolites for ammonium removal from aqueous solution.

In the aqueous solution, ammonium can exist in either the nonionised form $\left(\mathrm{NH}_{3}\right)$ and/or ionised form $\left(\mathrm{NH}_{4}^{+}\right)$depending on the $\mathrm{pH}$ and temperature. Of these two forms of ammonium, only the ionised one can be removed by the ion-exchange process. The equilibrium-exchange capacity remains constant up to $\mathrm{pH}$ 7. For optimum ion-exchange operation, the $\mathrm{pH}$ of the aqueous solution must be at or below 7 .

Ion-exchange is an endothermic process. Hence, an increase in temperature tends to incrase the exchange capacity of this process (Lin and $\mathrm{Wu}, 1996)$.

During the ion-exchange process, the $\mathrm{Na}^{+}$ion is replaced by the $\mathrm{NH}_{4}^{+}$ion, and hence the $\mathrm{Na}^{+}$ion concentration increases in the liquid phase during the ion-exchange processes. When the ion-exchanger reaches breakthrough, the upflow or downflow regeneration method is applied. Gaspard et al. (1983) reported that the upflow regeneration is more attractive than down-flow regeneration.

The ammonium ion-exchange capacity varies depending on the presence of another cations in the aqueous phase and initial ammonium concentration (Gaspard et al., 1983; Lin and Wu, 1996; Singh and Prasad, 1997; Demir et al., 1998). The ion-exchange capacity is influenced significantly by chemical and physical pretreatment techniques and loading or regeneration of clinoptilolite. The influence of a pretreatment on ion-exchange capacity varied widely depending on the source of clinoptilolite (Klieve and Semmens, 1980).

The present work considers ammonium removal by a natural ion-exchange resin. This investigation concentrates on defining various operational parameters necessary to remove ammonium efficiently through ion-exchange by using the zeolite, clinoptilolite. The main objective of this study is to evaluate the capacity of 


\begin{tabular}{|l|c|c|c|}
\hline \multicolumn{4}{|c|}{ TABLE 1 } \\
Chemical properties of Bigadiç zeolite tuffs \\
\hline $\begin{array}{l}\text { Component } \\
\text { (\%) }\end{array}$ & $\begin{array}{r}\text { Yücel and } \\
\text { Çulfaz, 1985 }\end{array}$ & $\begin{array}{c}\text { Çelenli } \\
\text { et al., 1994 }\end{array}$ & $\begin{array}{c}\text { Sirkecioglu } \\
\text { and Senatlar, } \\
1995\end{array}$ \\
\hline & & & - \\
$\mathrm{SiO}_{4}$ & - & 67.96 & 64.99 \\
$\mathrm{SiO}_{2}$ & 67.6 & - & 9.99 \\
$\mathrm{Al}_{2} \mathrm{O}_{3}$ & 11.3 & 10.74 & 1.95 \\
$\mathrm{~K}_{2} \mathrm{O}$ & 2.17 & 3.01 & 3.51 \\
$\mathrm{CaO}$ & 3.26 & 0.74 & 0.18 \\
$\mathrm{Na}_{2} \mathrm{O}$ & - & 0.81 & 1.01 \\
$\mathrm{MgO}_{\mathrm{Si}}$ & 1.18 & 1.49 & - \\
$\mathrm{Fe}_{2} \mathrm{O}_{3}$ & - & 15.36 & 3.99 \\
$\mathrm{MnO}_{\mathrm{TiO}}$ & 0.77 & - & - \\
$\mathrm{NaO}_{2}$ & 0.02 & - & - \\
$\mathrm{H}_{2} \mathrm{O}$ & 0.07 & - & - \\
\hline
\end{tabular}

\begin{tabular}{|l|c|c|c|c|c|c|}
\hline \multicolumn{7}{|c|}{ TABLE 2} \\
Sieve analysis of fine zeolite particles \\
\hline $\begin{array}{l}\text { Sieve opening, mm } \\
\% \text { Passing sieve }\end{array}$ & 1.00 & 0.60 & 0.50 & 0.30 & 0.25 & 0.125 \\
64 & 54 & 28 & 20 & 0 \\
\hline
\end{tabular}

Bigadiç clinoptilolite for removing ammonium ions from aqueous solutions under varying conditions.

\section{Materials and methods}

In this study, two different clinoptilolite forms were used. One of them was raw clinoptilolite and the other a conditioned clinoptilolite which was used after the first regeneration. The experiments were conducted in two phases with investigations using batch sorption and column studies.

\section{Chemical and physical properties of the zeolite clinoptilolite}

The ion-exchanger used in the experiments was obtained from Bigadiç, in the north-western part of Turkey. The natural zeolite was chosen on the basis of its good ammonium-ion selectivity and potentially low cost. The chemical properties of the clinoptilolite used in this study are given in Table 1.

The effective particle size was $0.18 \mathrm{~mm}$ with a uniformity coefficient of 2.98 for the fine particles. The sieve analysis is provided in Table 2.

Zeolite was broken into pieces and sieved into a diameter of $(-1.00+0.125)$ and $(-2.00+1.00) \mathrm{mm}$ (numbers in the parentheses indicate sieve size in $\mathrm{mm}$ through which particles passed and were retained, respectively). The zeolite was then washed with distilled water to remove turbidity and after drying in an oven for over an hour at $70^{\circ} \mathrm{C}$, was put in a desiccator.

\section{Test chemicals and analysis}

Ammonium chloride stock solution $\left(1000 \mathrm{mg} / \mathrm{NH}_{4}^{+}\right)$was prepared by dissolving $\mathrm{NH}_{4} \mathrm{Cl}$ in deionised water. The solution was further

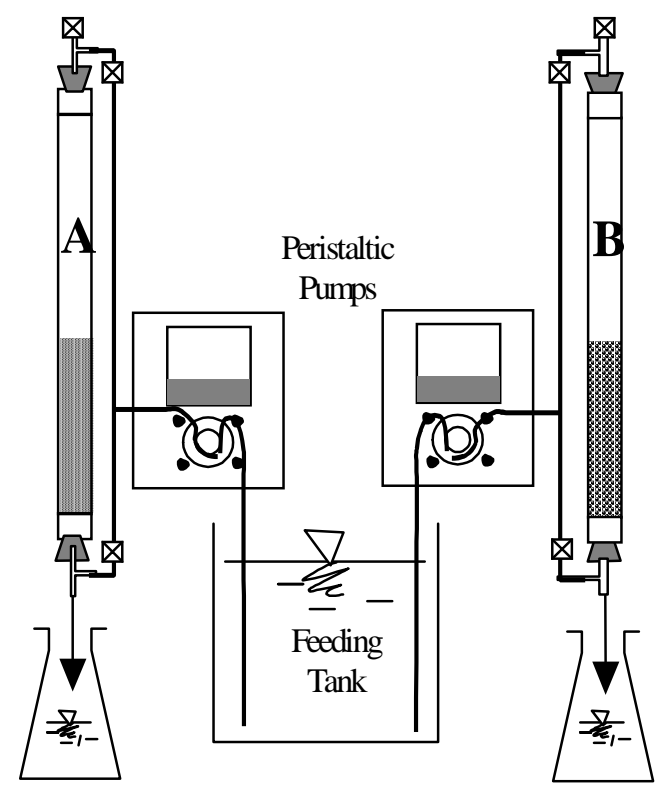

Figure 1

The experimental set-up

diluted before use. The ammonium chloride and other chemicals used were of analytical grade. Synthetic samples were prepared to give ammonium concentrations of 10, 20,40 and $80 \mathrm{mg} / \mathrm{l}$ by adding appropriate amounts of ammonium chloride stock solution to distilled water.

The ammonium concentration of the samples was determined by the standard Nesslerisation method using Pharmacia LKBNowaspec-spectrophotometer (StandardMethods, 1983). It should be noted that no more than $10 \mathrm{ml}$ of sample was taken for measurement of ammonium, and hence the total volume of the aqueous solution was affected insignificantly by sampling.

\section{Batch studies}

In the first phase of runs, batch sorption isotherms for the removal of ammonium were investigated. Batch sorption isotherms were determined in $500 \mathrm{ml}$ conical flasks. Weighed amounts $(0.4 \mathrm{~g})$ of clinoptilolite were introduced into four conical flasks, to which $400 \mathrm{ml}$ of ammonium solution concentrations of between 10 and $80 \mathrm{mg} / \mathrm{l}$ were added.

The flasks were shaken for $30 \mathrm{~min}$ and samples were taken periodically for measurement of aqueous-phase ammonium concentration. Preliminary tests confirmed that a $30 \mathrm{~min}$ contact time was enough to reach a steady-state ammonium concentration.

\section{Column studies}

In this study, two columns (A and B) each with an inner diameter of $15 \mathrm{~mm}$ were used. The bed height and volume of the columns were $140 \mathrm{~mm}$ and $25 \mathrm{~cm}^{3}$, respectively. Column A was filled with fine zeolite $(-1.00+0.125) \mathrm{mm}$ and Column $\mathrm{B}$ was filled with a coarse zeolite $(-2.00+1.00) \mathrm{mm}$.

In the column studies, operation and regeneration parameters, and ion-exchange capacity of clinoptilolite were investigated. Two peristaltic pumps (Watson Marlow 505L) were employed to feed the stock solution to the ion-exchange column at the desired flow rate. The ammonium concentration of the samples collected from the column exit was monitored. No stratification in the combined 


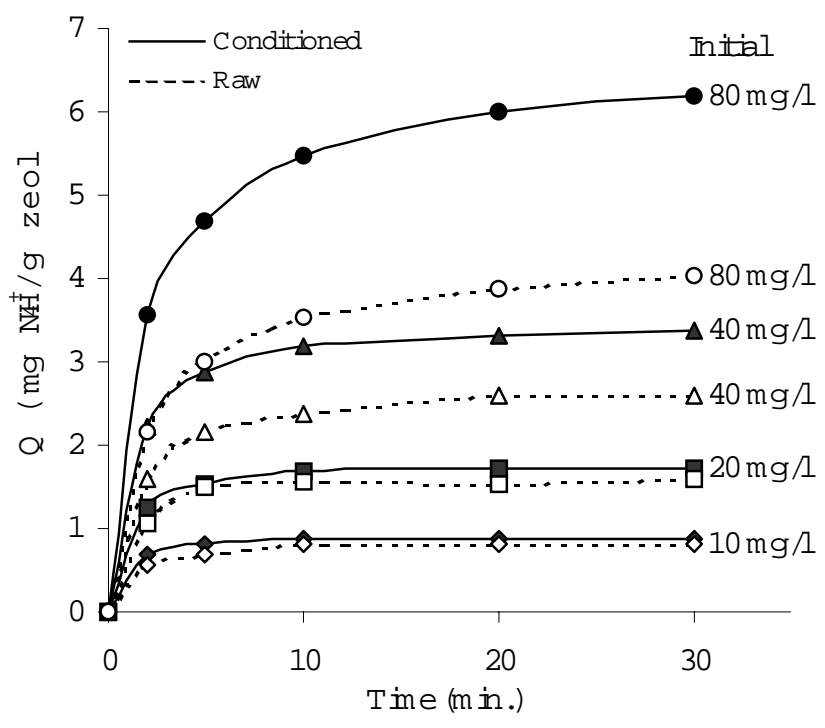

Figure 2

Effect of initial ammonium concentration in the aqueous solution on the exchange capacity at $20^{\circ} \mathrm{C}$ and $\mathrm{pH} 7-7.5$

scheme was observed under the flow rates employed. The basic experimental setup is shown in Fig. 1.

The resin column was exhausted by downflow at three different superficial velocities of 25,50 and 75 bed volume (BV)/h, until an ammonium breakthrough of more than $2 \mathrm{mg} / \mathrm{N} \mathrm{H}_{4}{ }^{+} \mathrm{N}$ was achieved. The columns were then regenerated with two different $\mathrm{NaCl}$ solutions $(10 \mathrm{~g} \mathrm{NaCl} / \mathrm{l}$ and $20 \mathrm{~g} \mathrm{NaCl} / \mathrm{l})$ and at two different superficial velocities, namely, $16 \mathrm{BV} / \mathrm{h}$ and $25 \mathrm{BV} / \mathrm{h}$. The regenerant was passed through the column in the upflow mode. The absence of ammonium in the effluent indicated the completion of regeneration. Another loading cycle was then carried out.

\section{Results and discussion}

\section{Sorption isotherms}

The Langmuir and Freundlich parameters were determined by the following procedures. The amount of ammonium accumulated on the clinoptilolite was calculated by the following expression as the difference between the amount present in the initial ammonium concentration and that remaining in solution after equilibrium with the clinoptilolite.

$$
\mathrm{Q}=\frac{\left(\mathrm{C}_{\mathrm{o}}-\mathrm{C}_{\mathrm{e}}\right) \mathrm{V}}{\mathrm{M}}
$$

where:

$\mathrm{Q}(\mathrm{mg} / \mathrm{g})$ is the amount of ammonium adsorbed

C $(\mathrm{mg} / \mathrm{l})$ represents initial ammonium concentration

$\mathrm{C}_{\mathrm{e}}(\mathrm{mg} / \mathrm{l})$ represents equilibrium ammonium concentration

$\mathrm{V}(\mathrm{I})$ is the volume of solution

$\mathrm{M}(\mathrm{g})$ is the mass of zeolite.

Results determined by using Eq. (1) are plotted vs. time and shown in Fig. 2 for the fine $(-1.00+0.125) \mathrm{mm}$ clinoptilolite.

The initial ammonium concentration provides the necessary driving force to overcome all mass-transfer resistances of ammonium between the aqueous and solid phases. The removal of ammonium is high in the initial $5 \mathrm{~min}$, but thereafter the rate significantly levels off and eventually approaches zero, i.e. when equilibrium is attained. These changes in the rate of removal might be due to the

\begin{tabular}{|c|c|c|}
\hline \multicolumn{3}{|c|}{$\begin{array}{l}\text { TABLE } 3 \\
\text { Langmuir and Freundlich models para- } \\
\text { meters for best fit and corresponding } \\
\text { correlation coefficients }\end{array}$} \\
\hline & Raw zeolite & Conditioned \\
\hline \multicolumn{3}{|c|}{ Freundlich model } \\
\hline $\begin{array}{c}\mathrm{K}_{\mathrm{f}} \\
1 / \mathrm{n} \\
\mathrm{r}^{2}\end{array}$ & $\begin{array}{l}0.608 \\
0.537 \\
0.956\end{array}$ & $\begin{array}{l}0.806 \\
0.727 \\
0.989\end{array}$ \\
\hline \multicolumn{3}{|c|}{ Langmuir model } \\
\hline $\begin{array}{l}\mathrm{K}_{\mathrm{L}} \\
\mathrm{A}^{2} \\
\mathrm{r}^{2}\end{array}$ & $\begin{array}{l}0.440 \\
0.085 \\
0.992\end{array}$ & $\begin{array}{l}0.770 \\
0.069 \\
0.999\end{array}$ \\
\hline
\end{tabular}

fact that, initially, all adsorbent sites were vacant and the solute concentration gradient was high. Afterwards, the ammonium uptake rate by the zeolite decreased significantly, due to decrease in adsorption sites. A decreasing removal rate, particularly towards the end of the experiment, indicated a possible monolayer of ammonium ions on the outer surface and pores of the zeolite and pore diffusion onto the inner surface of zeolite particles through the film due to continuous agitation maintained during the experiment.

The adsorption rate of ammonium by both raw and conditioned clinoptilolite was initially fast, during the first 5 to $10 \mathrm{~min}$, depending on the initial ammonium concentration, and then gradually decreased with increase in contact time. With the increase of ammonium concentration in solution, the adsorption capacity of the ammonium ion also increases. Singh and Prasad (1997) observed that with high concentrations of ammonium $\left(98.76 \mathrm{mg} \mathrm{NH}_{4}^{+} / 100\right.$ $\mathrm{ml}$ ), adsorption by $13 \mathrm{X}$ molecular sieve synthetic zeolites becomes constant, possibly because of complete removal of $\mathrm{Na}^{+}$by $\mathrm{NH}_{4}^{+}$ cations.

The equilibrium removal of the ammonium ion considered can be mathematically expressed in terms of adsorption isotherms. Adsorption isotherm data are commonly fitted to the Freundlich or the Langmuir models as:

$$
\mathrm{Q}=\mathrm{K}_{\mathrm{f}} \mathrm{C}_{\mathrm{e}}^{1 / \mathrm{n}}
$$

or

$$
\mathrm{Q}=\frac{\mathrm{K}_{\mathrm{L}} \mathrm{C}_{\mathrm{e}}}{1+\mathrm{a} \mathrm{C}_{\mathrm{e}}}
$$

respectively, where:

$\left(\mathrm{K}_{\mathrm{f}}\right)$, and $(1 / \mathrm{n})$ are indicative isotherm parameters of sorption capacity and intensity, respectively

$\left(\mathrm{K}_{\mathrm{L}}\right)$ and (a) are Langmuir model parameters.

These models are rearranged to the linear form by taking logarithms on both sides.

$$
\begin{aligned}
& \log \mathrm{Q}=\log \mathrm{K}_{\mathrm{f}}+\mathrm{n} \log \mathrm{C}_{\mathrm{e}} \\
& \mathrm{C}_{\mathrm{e}} / \mathrm{Q}=1 / \mathrm{K}_{\mathrm{L}}+\left(\mathrm{a} / \mathrm{K}_{\mathrm{L}}\right) \mathrm{C}_{\mathrm{e}}
\end{aligned}
$$

Plotting the experimental data using Eqs. (4) and (5) in Figs. 3 and 4 indicates that both models give good fit for the data. The values of $\left(\mathrm{K}_{\mathrm{L}}\right),(\mathrm{a}),\left(\mathrm{K}_{\mathrm{f}}\right)$ and $(1 / \mathrm{n})$ that best fitted the data as well as the corresponding correlation coefficients are presented in Table 3. 

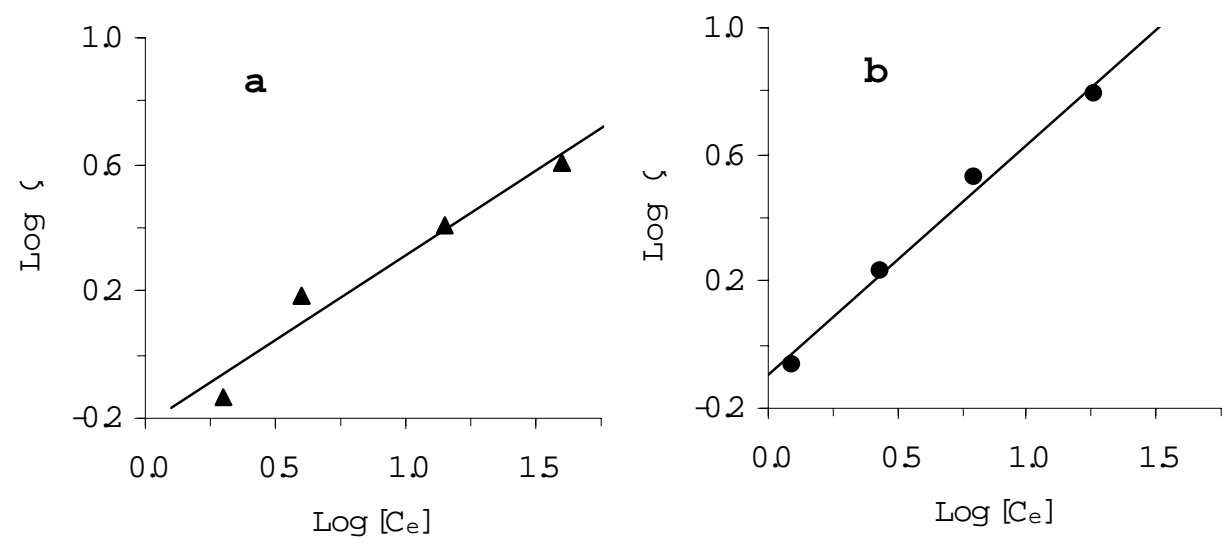

Figure 3

Linearised Freundlich isotherm for ammonium removal by zeolite (10 g zeolite/l and $20^{\circ} \mathrm{C}$ ); a: Raw; b: Conditioned
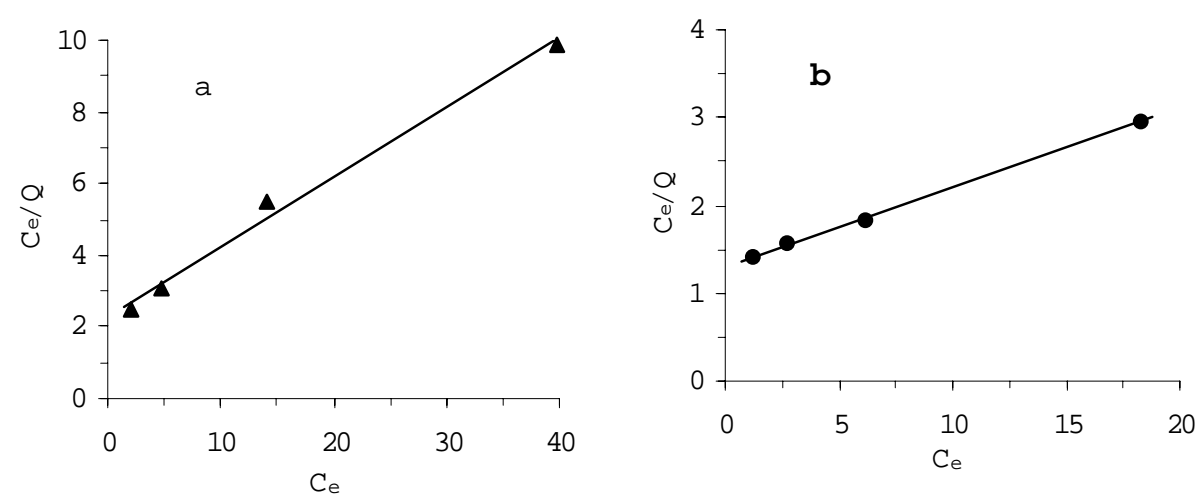

Figure 4

Linearised Langmuir isotherm for ammonium

removal by zeolite (10 g zeolite/l and $20^{\circ} \mathrm{C}$ ); a: Raw; b: Conditioned
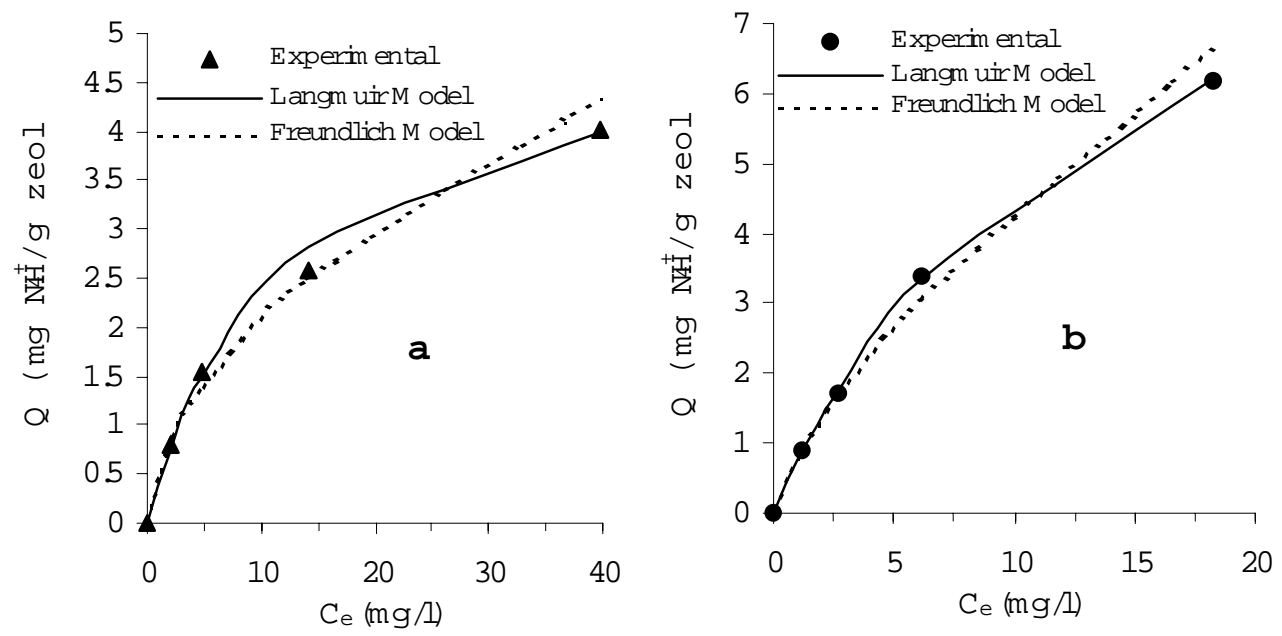

Figure 5

Comparison of the

Freundlich and Langmuir adsorption isotherms for ammonium ion removal; a: Raw; b: Conditioned.
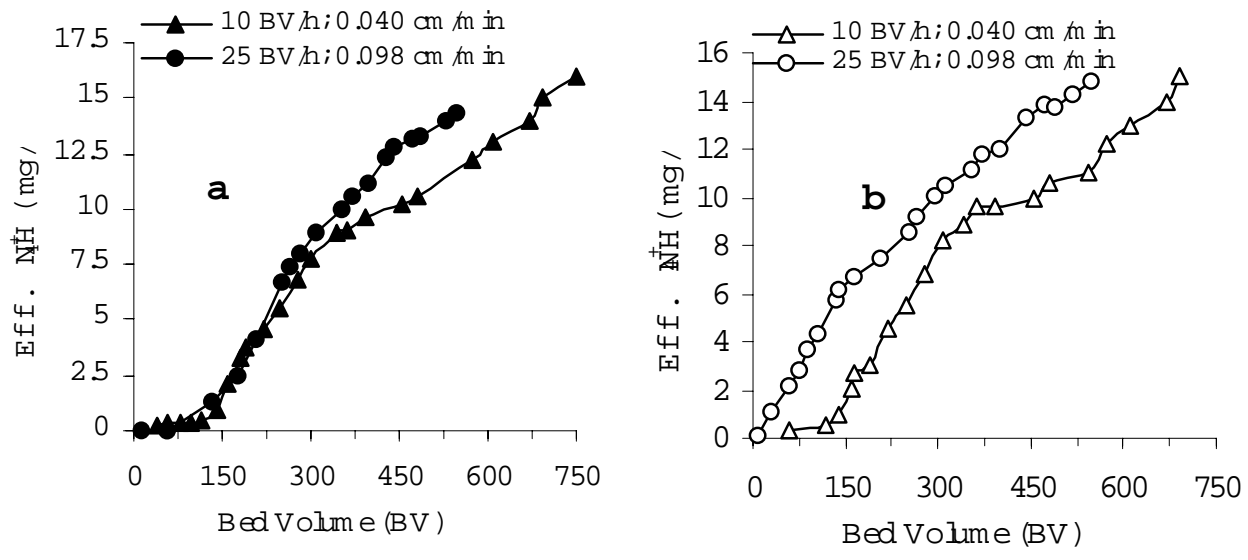

\section{Figure 6}

Effect of the superficial velocity on the breakthrough curve of ammonium removal at 20 $\mathrm{mg} / \mathrm{l} \mathrm{NH}{ }_{4}^{+}$initial ammonium concentration for raw zeolite;

a: $(-1.00+0.125) \mathrm{mm}$; b: $(-2.0+1.0) \mathrm{mm}$ 


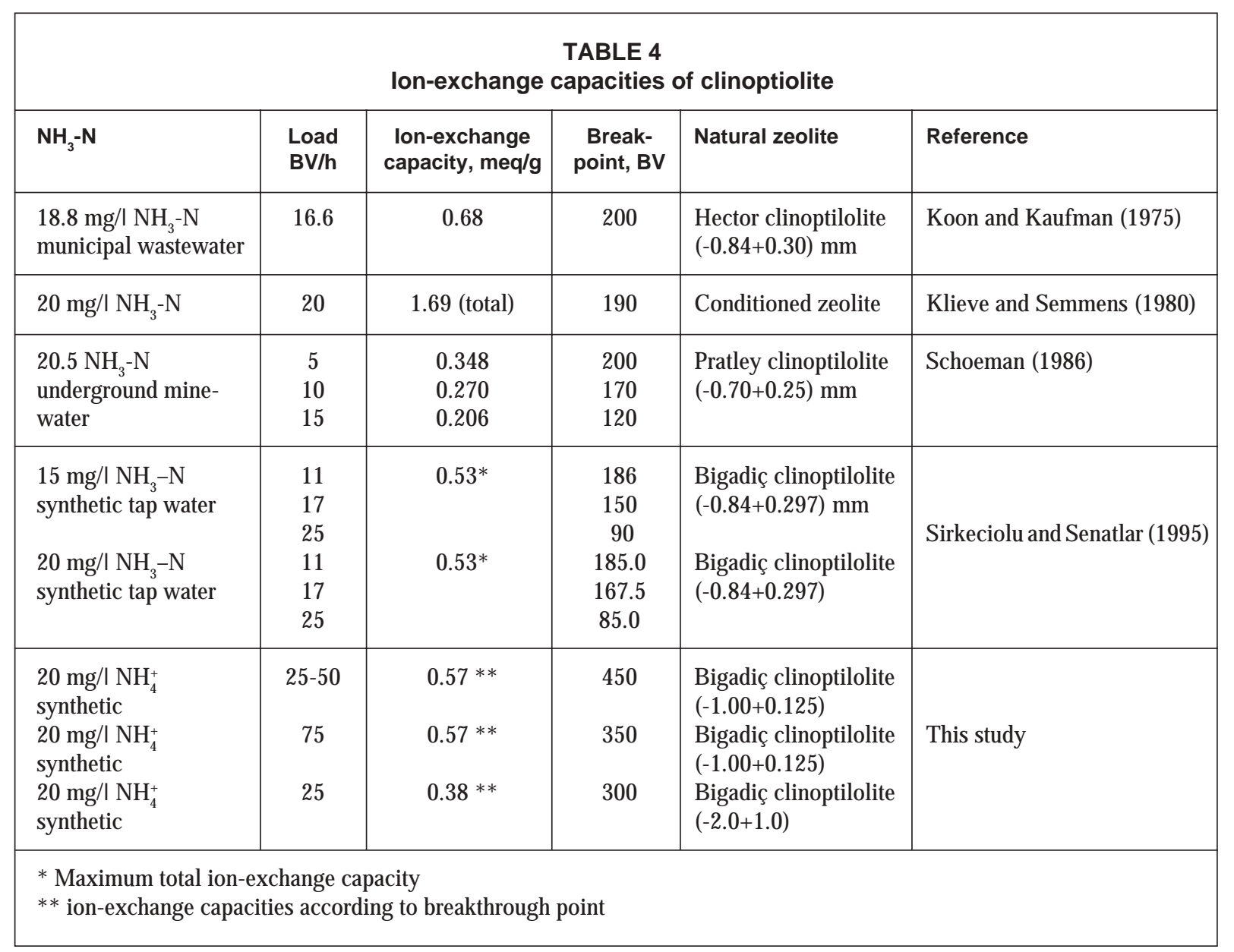

The comparisons of each of the models with the data are presented in Fig. 5.

As a consequence, the Freundlich and Langmuir isotherms for ammonium removal, on the raw clinoptilolite can be represented by the following empirical formula:

$$
\mathrm{Q}=0.608 \mathrm{C}_{\mathrm{e}}^{0.537}
$$

and

$$
\mathrm{Q}=\frac{0.44 \mathrm{C}_{\mathrm{e}}}{1+0.085 \mathrm{C}_{\mathrm{e}}}
$$

respectively. For the conditioned clinoptilolite, the Freundlich and Langmuir isotherms are obtained as follows:

$$
\mathrm{Q}=0.806 \mathrm{C}_{\mathrm{e}}^{0.727}
$$

and

$$
\mathrm{Q}=\frac{0.77 \mathrm{C}_{\mathrm{e}}}{1+0.069 \mathrm{C}_{\mathrm{e}}}
$$

respectively.

\section{Column studies}

The concentrations of the solution for column studies were prepared synthetically at the level of $20 \mathrm{mg} / \mathrm{l}$ of $\mathrm{NH}_{4}^{+}$. The breakthrough curves of ammonium removal by clinoptilolite are shown in Figs. 6 and 7 for various superficial velocities of the aqueous solution.
The average ammonium leakage before breakthrough was less than $0.5 \mathrm{mg} / \mathrm{l}$ for Column-A after the first regeneration (Fig. 7 a). Changing the flow rate from 10 to $25 \mathrm{BV} / \mathrm{h}$ resulted in no significant decrease in ammonium adsorption capacity for the fine and the coarse raw clinoptilolite (Fig. 6).

The capacity to $1 \mathrm{mg} / \mathrm{NH}_{4}{ }^{+}$breakthrough was reached in 450 $\mathrm{BV}$ for the fine clinoptilolite $(-1.00+0.125)$ column with superficial velocities of both 25 and $50 \mathrm{BV} / \mathrm{h}$. On the other hand, the capacity of $1 \mathrm{mg} / \mathrm{N} \mathrm{NH}_{4}^{+}$breakthrough was reached in $350 \mathrm{BV}$ for the fine zeolite column with superficial velocity of $75 \mathrm{BV} / \mathrm{h}$. As the superficial velocity of the aqueous solution decreases, the hydraulic residence time increases, resulting in more $\mathrm{NH}_{4}^{+}$being removed by the ion-exchange resin. Ion-exchange capacities of clinoptiolite are given in Table 4.

The particle size of $(-1.0+0.125) \mathrm{mm}$ zeolite gives a higher ammonium adsorption capacity than that of the $(-2.0+1.0) \mathrm{mm}$ zeolite particle size. The adsorption capacities calculated by graphical integration of the area above the breakthrough curves are about 0.57 and $0.38 \mathrm{meq} / \mathrm{g} \mathrm{NH}_{4}^{+}$for particle sizes ranging between $(-1.0+0.125)$ and $(-2.0+1.0) \mathrm{mm}$, respectively. This indicates that the smaller particle size has a higher ion-exchange capacity due to greater available surface area.

Five loading and four regeneration cycles were carried out without loss of $\mathrm{NH}_{4}^{+}$adsorption capacity. It is further observed that after the 1 st regeneration, ammonium adsorption capacity of zeolite was increased. This shows that on regeneration of the zeolite column with $\mathrm{NaCl}$ solution, the $\mathrm{Na}$ ions have activated the zeolite column. After the 2nd and 3rd regenerations, the loading process was repeated and it was found that the ammonium adsorption 

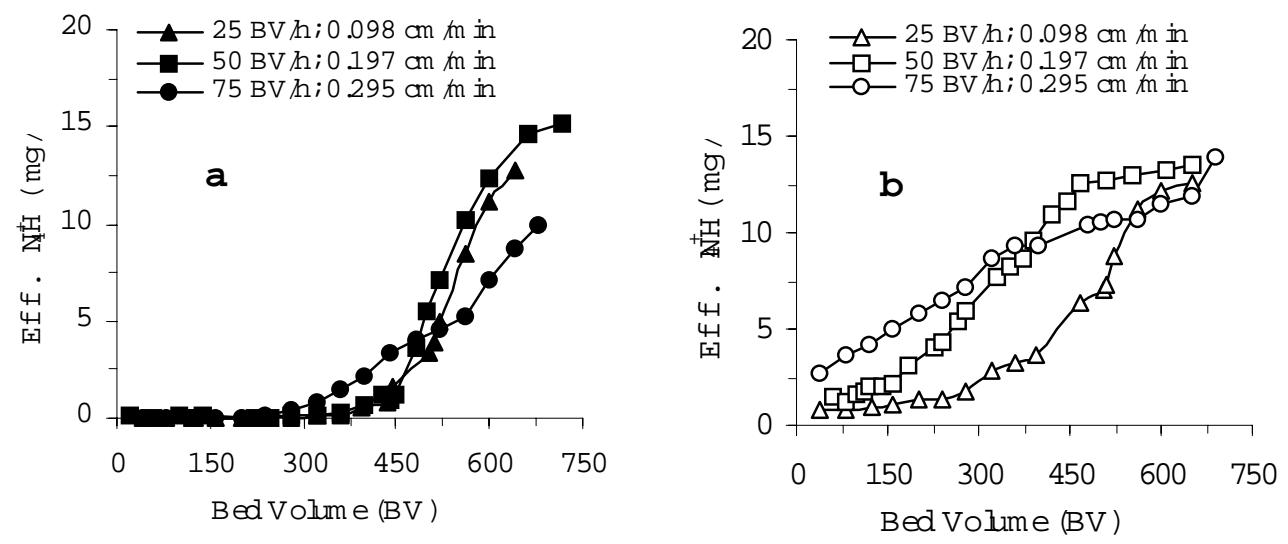

Figure 7

Effect of the superficial velocity on the breakthrough curve of ammonium removal at $20 \mathrm{mg} / \mathrm{l} \mathrm{NH}{ }_{4}^{+}$initial ammonium concentration for conditioned zeolite; a: $(-1.00+0.125) \mathrm{mm}$; b: $(-2.0+1.0) \mathrm{mm}$
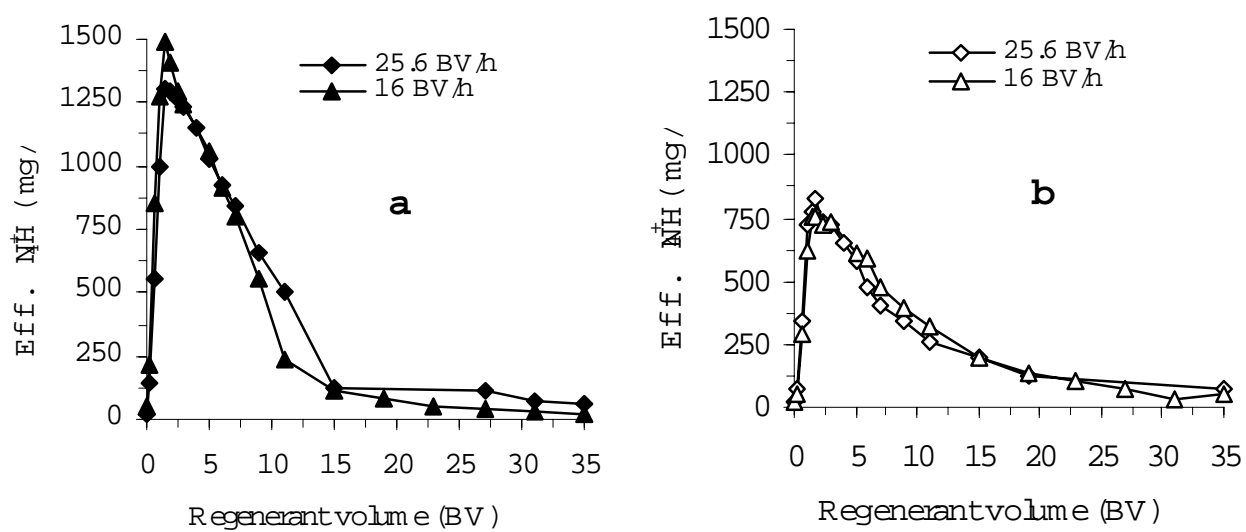

Figure 8 Ammonium elution (10 gr NaCl/l, pH 12.3); a: $(-1.00+0.125) \mathrm{mm}$; b: $(-2.0+1.0) \mathrm{mm}$

Regenerant volum e (BV)
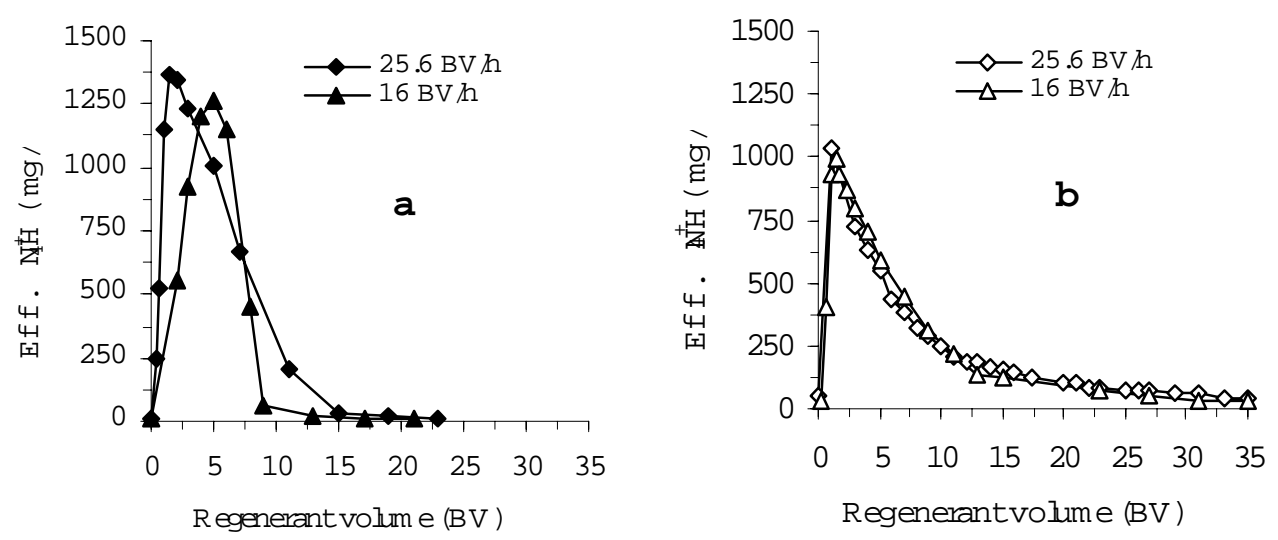

Figure 9

Ammonium elution (20 gr NaCl/l, pH 12.3); a: $(-1.00+0.125) \mathrm{mm}$; b: $(-2.0+1.0) \mathrm{mm}$

capacity of the clinoptilolite remained constant. This indicates that using $\mathrm{NaCl}$ solution, the regeneration of the column could be done repeatedly without loss of ammonium adsorption capacity.

\section{Regeneration}

Columns were prepared by complete regeneration with $35 \mathrm{BV}$ of regenerant containing 10 and $20 \mathrm{~g} \mathrm{NaCl} / \mathrm{l}$ and a $\mathrm{pH}$ of 12.3 adjusted by using $\mathrm{NaOH}$. Ammonium elution by 10 and $20 \mathrm{~g} \mathrm{NaCl} / \mathrm{l}$ regenerant solutions is shown in Figs. 8 and 9, respectively. $15 \mathrm{BV}$ of regenerant, corresponding to the use of $20 \mathrm{~g} \mathrm{NaCl} / \mathrm{l}$ were sufficient to reduce the effluent ammonium concentration in the regenerant to less than $20 \mathrm{mg} / \mathrm{l}$ for the fine zeolite column (Fig. 9a). On the other hand, after feeding $15 \mathrm{BV}$ of regenerant to the coarse zeolite column containing 10 and $20 \mathrm{~g} \mathrm{NaCl} / \mathrm{l}$, effluent ammonium concentrations were about 200 and $150 \mathrm{mg} / \mathrm{l}$, respectively. The coarse zeolite column needs more regenerant solution than the fine zeolite column for complete regeneration.

It is concluded from Figs. 8 and 9 that a volume of $15 \mathrm{BV}-0.35$ $\mathrm{M} \mathrm{NaCl}$ solution is sufficient for nearly complete regeneration of the zeolite column of $(-1.00+0.125) \mathrm{mm}$ particle size. The coarse zeolite needs more regenerant solution than the fine zeolite for complete regeneration and regeneration seems to be completed when 25 to 35 bed volumes of regenerant solution pass the ionexchanger bed for both of the columns.

Results of the experimental investigation are used to develop optimum operational conditions for clinoptilolite exchangers.

\section{Conclusion}

The removal of ammonium from synthetic solution was demonstrated successfully on a laboratory scale with a selective 
ion-exchange process. The following conclusions can be drawn from this study:

- The data obtained from batch studies were applied to Langmuir and Freundlich isotherms. The Langmuir isotherm gives an adequate correlation coefficient value compared to the Freundlich isotherm correlation isotherm.

- The particle size of $(-1.00+0.125) \mathrm{mm}$ zeolites gives higher ammonium adsorption capacity than that of $(-2.0+1.0) \mathrm{mm}$ particle size of zeolites. The adsorption capacities calculated by graphical integration of the area above the breakthrough curves are about 0.57 and $0.38 \mathrm{meq} / \mathrm{g} \mathrm{NH}_{4}{ }^{+}$for particle sizes ranging between $(-1.0+0.125)$ and $(-2.0+1.0) \mathrm{mm}$, respectively.

- The capacity to $1 \mathrm{mg} / \mathrm{N} \mathrm{NH}_{4}{ }^{+}$breakthrough was reached in 450 BV for the fine clinoptilolite $(-1.00+0.125)$ column with superficial velocities of both 25 and $50 \mathrm{BV} / \mathrm{h}$. On the other hand, the capacity of $1 \mathrm{mg} / \mathrm{l} \mathrm{NH}{ }_{4}^{+}$breakthrough was reached in $350 \mathrm{BV}$ for the fine zeolite column with superficial velocity of $75 \mathrm{BV} / \mathrm{h}$. A flow rate of 25 to $50 \mathrm{BV} / \mathrm{h}$ loading is advocated. It is a reasonable velocity and has no negative effect on adsorption capacity.

- The capacity increases considerably with the first regeneration. It seems that the clinoptilolite has been activated by the regenerant containing 10 and $20 \mathrm{~g} / \mathrm{l} \mathrm{NaCl}$ and a $\mathrm{pH}$ of 12.3 adjusted by using $\mathrm{NaOH}$. Regeneration can be accomplished with about $10 \mathrm{BV}$ of regenerant containing $20 \mathrm{~g} / \mathrm{l} \mathrm{NaCl}$ applied at a rate of $16 \mathrm{BV} / \mathrm{h}$ for fine clinoptilolite. After the $2 \mathrm{nd}$ and $3 \mathrm{rd}$ regenerations ammonium adsorption capacity of zeolite remained constant. The columns could be regenerated a number of times without loss of ammonium adsorption capacity.

\section{Acknowledgments}

We gratefully acknowledge financial support for this project from the Istanbul Water and Sewerage Administration (ISKI). We would also like to thank Dr. Z. Sen (I.T.Ü.) for his kind suggestions during the discussion of the results and the data elaboration.

\section{References}

AHMED S, CHUGHTAI S and KEANE MA (1998) The removal of cadmium and lead from aqueous solution by ion-exchange with $\mathrm{Na}-\mathrm{Y}$ zeolite. Separation and Purification Technol. 13 (1) 57-64.

CALLEJAS RL, GEHR R, JOMÉNEZ BE and ALVAREZ PJJ (2001) Heavy metal removal with mexican clinoptilolite: multi-component ionic exchange. Water Res. 35 (2) 373-378.

ÇELENLI A, BÜRTÜK Y and SURNER F (1994) Industrial usage of heavy metal ions, an example from Turkey. Paper presented at Int. Segmite $2^{\text {nd }}$ Conf., April 4-7, Karaci.

DEMIR A, DEBIK Eand GÜNAY A (1998) Evsel atiksulardan amonyumun gideriminde iyon degistirici olarak dogal zeolit kullaniminin arastirilmasi. ISKI Projesi Yildiz, Istanbul.

GASPARD M, NEVEU A and MARTIN G (1983) Clinoptilolite in drinking water treatment for $\mathrm{NH}_{4}^{+}$removal. Water Res. 17 (3) 279-288.

HARALAMBOUS A, MALIOU E and MALAMIS M (1992) The use of zeolite for ammonium uptake. Water Sci. Technol. 25 (1) 139-145.

JORGENSEN SE and BARKACS K (1976) Ammonium removal by use of clinoptilolite. Water Res. 10 213-224.

KLIEVE JR and SEMMENS MJ (1980) An evaluation of pretreated natural zeolites for ammonium removal. Water Res. 14 161-168.

KOON JH and KAUFMAN WJ (1975) Ammonium removal from municipal wastewaters by ion-exchange. J. WPCF 47 (3) 448-465.

LIN SH and WU CL (1996) Ammonium removal from aqueous solution by ion-exchange. Ind. Eng. Chem. Res. 35 553-558.

MERCER BW, AMES LL, TOUHILL JC, VAN SLYKE WJ and DEAN RB (1970) Ammonium removal from secondary effluents by selective ion-exchange. J. WPCF. 42 (2) R95-R107.

METCALF and EDDY INC. (1991) Wastewater Engineering: Treatment, Disposal and Reuse (3 ${ }^{\text {nd }}$ edn.) Mc Graw Hill Co., New York.

OUKISK and KAVANNAGHM (1999) Treatment of metals-contaminated wastewaters by use of natural zeolites. Water Sci. Technol. 39 (10-11) $115-122$.

SCHOEMAN JJ (1986) Evaluation of a South African clinoptilolite for ammonium-nitrogen removal from an underground mine water. Water SA 12 (2) 73-82

SINGH G and PRASAD B (1997) Removal of ammonium from cokeplant wastewater by using synthetic zeolite. Water Environ. Res. 69 (2) 157-161.

SIRKECIOGLU A and SENATLAR A (1995) Removal of ammonium ions from wastewaters by Bigadiç clinoptilolite. Tr. J. of Eng. and Environ. Sci. 19 399-405.

STANDARD METHODS (1989) Standard Methods for the Examination of Water and Wastewater (17 $7^{\text {th }}$ edn.). American Public Health Association, Washington DC.

YÜCEL H and ÇULFAZ A (1985) Yerel ve dogal klinoptilolit zeolitinin fiziksel ve kimyasal özellikleri. Doga Bilim Dergisi 9 (3) 288-296. 
